\title{
Diversity of Arbuscular Mycorrhizal Fungi of Durum Wheat (Triticum durum Desf.) Fields of the East of Algeria
}

\author{
Wassila Nadji ${ }^{1}$, Nadir Belbekri ${ }^{1}$, Nadia Ykhlef $^{1}$ \& Abdelhamid Djekoun ${ }^{1}$ \\ ${ }^{1}$ Laboratory of Genetics, Biochemistry and Plant Biotechnology 'Team II Biotechnolgy and Plant Amelioration', \\ Department of Biology and Ecology, Faculty of Natural Sciences and Life, Frères Mentouri University, \\ Constantine, Algeria \\ Correspondence: Wassila Nadji, Laboratory of Genetics, Biochemistry and Plant Biotechnology 'Team II \\ Biotechnolgy and Plant Amelioration', Department of Biology and Ecology, Faculty of Natural Sciences and \\ Life, Frères Mentouri University, Constantine, Algeria. Tel: 213-776-660-566. E-mail: wassila.nadji@, \\ umc.edu.dz
}

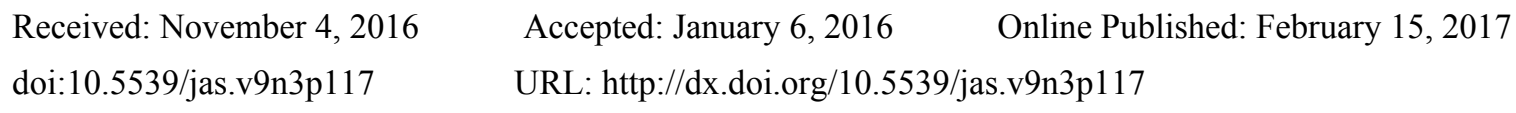

This work was supported by the Ministry of Higher Education and Scientific Research of Algeria.

\begin{abstract}
In Algeria, in the semi-arid and arid areas cereal production is limited because of many constraints like lack of mineral elements (phosphorus and nitrogen), low organic matter and an insufficient water reserve due to the low rainfall. Most researches on durum wheat (Triticum durum Desf.) are undertaken to increase its productivity. In recent years several methods have been used including using microorganisms. Arbuscular Mycorrhizal fungi (AMF) appear to have important roles in plants in various soil conditions. In Algeria and particularly in the eastern regions, the diversity of AMF spores in the soil is so far little studied. In this context this study focuses on the study of the diversity and the abundance of AMF spores in Triticum durum Desf. fields in arid, semi-arid and coastal regions. Soil samples were collected and characterized and the spores isolated by the wet sieving methods were observed, counted and identified. The results of the physic-chemical characterization of all soil samples reveal a clay loam, loam clay and loam sandy soils with an alkaline $\mathrm{pH}$ (7.54-8.27), a total nitrogen content from 0.023 to $0.082 \%$ and phosphorus content ranging from $1.63 \%$ to $7.74 \%$. We noted the presence of several morphotypes that were classified as follow: Glomeraceae, Acaulosporaceae and Scutellosporaceae with a predominance of Glomeraceae in different sites depending on climate and soil type. The presence of these families demonstrates a biodiversity of the eastern wheat fields of Algeria.
\end{abstract}

Keywords: Triticum durum Desf., endomycorrhizae, Glomus, Acaulospora, Scutellospora, Algeria

\section{Introduction}

Cereals are one of the most important crops in the world. They are a major source of food for both human's consumption and animal feed. In Algeria, the cereal and cereal derived food products occupy strategic place in our food system and our national economy as this culture covers more than $90 \%$ of the cultivated grounds (Djermoun, 2009).

The major cereal crop in our country is wheat which its production is exposed to various edaphic constraints (chemical, physical, biologic or climatic); especially those encountered in semi arid and arid regions. In research, several approaches are used for improving wheat production including AMF which are the principal symbiotic components of the soil edaphon and account for $25 \%$ of the biomass of the soil micro-fauna (Hamel, 1996).

Indeed, wheat is easily mycorrhized by AMF under controlled greenhouse conditions and under field conditions (Cade-Menun et al., 1991; Neveen \& Bahaa, 2011). These fungi have many advantages on the ecological level as well as the economic level, they establish symbiotic associations with plant roots, thus allowing the improvement of the agricultural products yield, and they translocate water and mineral nutrients such as phosphorus and nitrogen to the plants (Hu et al., 2010; Neveen \& Bahaa, 2011).They positively affect plants tolerance to both abiotic (soil salinity and drought) as well as biotic (pathogens) stresses (Allen \& Boosalis, 1983; Strullu et al., 1991). 
Studies showed that the AMF are not all the same, they are morphologically and physiologically different (Dai et al., 2014; Jansa et al., 2005; Brever et al., 2001).

Despite their significant presence in our natural environment, little is known about their biodiversity particularly in the durum wheat fields of Algeria. It is in this context that we carried on this study on the biodiversity, the identification and the characterization of indigenous AMF from 10 cereal fields of the East of Algeria.

\section{Material and Methods}

Study was taken up in 10 cereal fields of the east part of Algeria (Figure 1), covering a semi-arid area of the high plateau Tellian, an arid area characterized by a cold winter and a very hot summer, and a littoral area characterized by a soft winter and a hot dry summer.The major characteristics of these sites are presented in Table 1 where in each area, two repetitions were selected.

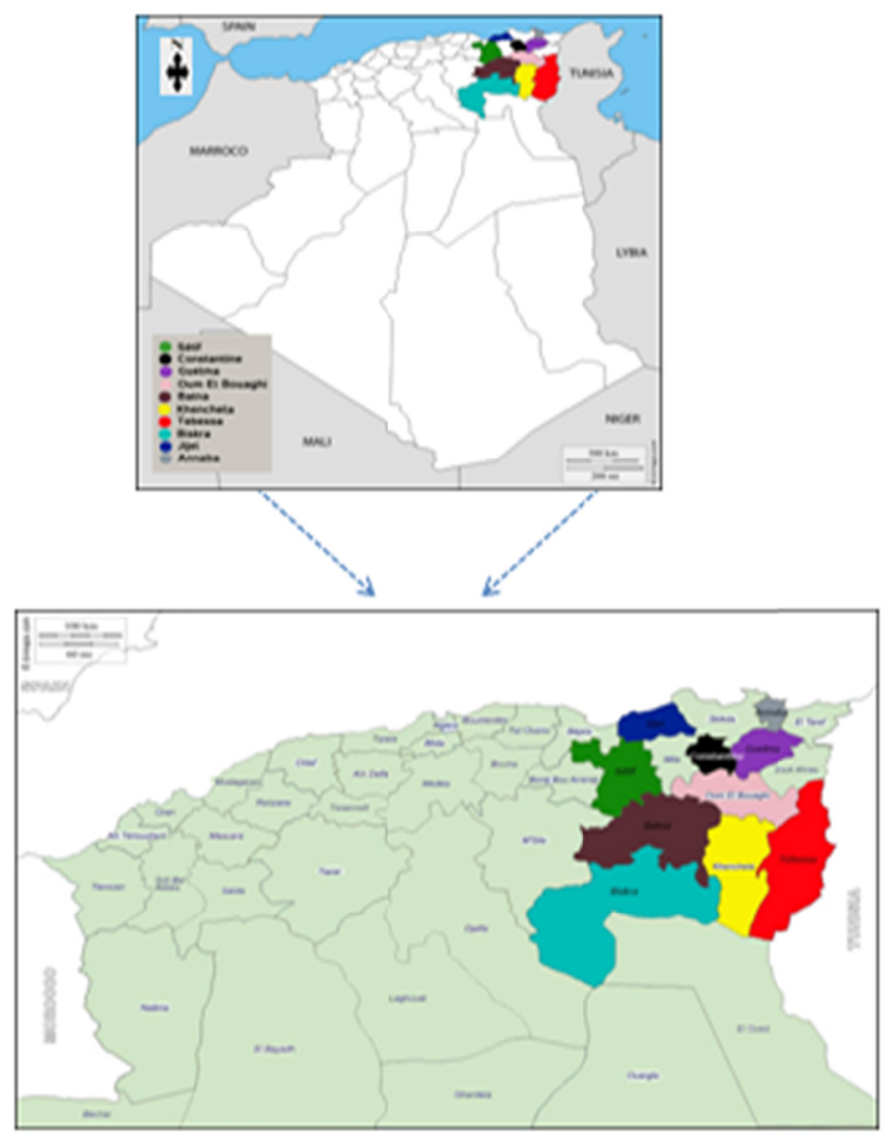

Figure 1. Localization of the Algerian East cereal fields

The soil samples were collected from 10 different sites of the eastern part of the country of Triticum durum Desf. fields. All the soil samples were collected from a depth of 0-30 cm were taken in March 2015, they were sieved ( $2 \mathrm{~mm}$ mesh), homogenized, and air dried in the shade, they were put in plastic bags and stored in the refrigerator at $4{ }^{\circ} \mathrm{C}$ until use for physico-chemical analysis of the soil properties and for the isolation and characterization of AMF spores.

\subsection{Physico-Chemical Analysis of the Soil}

The granulometric characterization of the soil samples are determined by wet sieving technique (Afnor, 1990), the $\mathrm{pH}$ and electrical conductivity (EC) were measured on soil suspensions by a digital $\mathrm{pH}$ meter and a digital conductivity meter respectively, total nitrogen and total phosphorus content were determined using the Kjeldahl method (Rinaudo, 1970). 
Table 1. Principal localizations of the cereal sitesof the east area of Algeria

\begin{tabular}{llll}
\hline Site & Coordinates & Pluviometry $(\mathrm{mm})^{1}$ & Culturale methods $^{2}$ \\
\hline Sétif & $36^{\circ} 09^{\prime} 00^{\prime \prime}$ Nor $5^{\circ} 26^{\prime} 00^{\prime \prime}$ Est & $00-08$ & Organic amendement (manure and compost) \\
Constantine & $36^{\circ} 13^{\prime} 57^{\prime \prime}$ Nor $6^{\circ} 56^{\prime} 39^{\prime \prime}$ Est & $00-08$ & Organic amendement (compost) \\
Guelma & $36^{\circ} 18^{\prime} 55^{\prime \prime}$ Nor $7^{\circ} 09^{\prime} 50^{\prime \prime}$ Est & $00-08$ & Organic amendement (manure and compost) \\
Oum El Bouaghi & $35^{\circ} 52^{\prime} 39^{\prime \prime}$ Nor $7^{\circ} 06^{\prime} 49^{\prime \prime}$ Est & $00-08$ & Organic amendement (manure) \\
Batna & $35^{\circ} 33^{\prime}$ Nor $6^{\circ} 10^{\prime}$ Est & $00-08$ & Organic amendement (manure and wood) \\
Khenchela & $35^{\circ} 25^{\prime} 55^{\prime \prime}$ Nor $7^{\circ} 08^{\prime} 40^{\prime \prime}$ Est & $00-08$ & Organic amendement (manure and compost) \\
Tébessa & $35^{\circ} 24^{\prime} 19^{\prime \prime}$ Nor $8^{\circ} 06^{\prime} 59^{\prime \prime}$ Est & $00-07$ & Organic amendement (manure, compost and wood) \\
Biskra & $34^{\circ} 51^{\prime} 00^{\prime \prime}$ Nor $5^{\circ} 44^{\prime} 00^{\prime \prime}$ Est & $00-07$ & Organic amendement (wood) \\
Jijel & $36^{\circ} 49^{\prime} 00^{\prime \prime}$ Nor $5^{\circ} 46^{\prime} 00^{\prime \prime}$ Est & $02-07$ & Organic amendement (manure) \\
Annaba & $36^{\circ} 54^{\prime} 15^{\prime \prime}$ Nor $7^{\circ} 45^{\prime} 07^{\prime \prime}$ Est & $02-07$ & Organic amendement (manure) \\
\hline
\end{tabular}

Note. ${ }^{1}$ Data from the Ministry of Agriculture and Rural Development website, agro meteorology cell, agricultural campaign of $2014 / 2015 .{ }^{2}$ A survey with farmers.

\subsection{Isolation and Identification of AM Spores}

The AM spores were isolated from $100 \mathrm{~g}$ of each soil sample by wet sieving and decanting technique of Gerdemann and Nicolson (1963).

The spore suspension has undergone a first centrifugation at 2000 RPM for 3 minutes in order to separate the spores from soil particles and root fragments, than a second centrifugation on a sucrose gradient at 2000RPM for 1 minute in order to collect spores of a similar size and density fraction. This spore suspension is poured into a Petri dish and each type of spores is sorted and counted under a binocular magnifying glass (Olympus SZX16).

All healthy spores were examined for their various morphological characters (color, form and size). The diameters of AMF spores are determined with an Image Pro Plus imaging system (4.0 version) attached to a compound microscope (Olympus BH-2). The AMF spores were identified with the help of identification manual of the of the Vesicular Arbuscular Mycorrhizal Fungi, certain species were also characterized on the basis of bibliographical data published on the web sites of INVAM (http://invam.caf.wvu.edu/fungi/taxnomy/speciesID) and BEG (http://www.kent.ac.uk/bio/beg/).

\subsection{Control of Mycorrhization}

Mycorrhization check was performed to confirm the level of colonization of wheat roots by AMF. Triticum durum Desf. Boussellem variety was provided by the Institut Technique des Grandes Cultures Khroub/ Constantine, Algeria (ITGC). The seeds were inoculated with the spores isolated from durum wheat fields (5 morphotypes) and put in plastic pots in the greenhouse at a temperature of $25 \pm 10{ }^{\circ} \mathrm{C}$ and relative humidity of $45 \pm 15 \%$ for 3 months. The effect of mycorrhization is determined by the staining method described by (Vierheilig et al., 1998), the entire root system of each plant was thoroughly rinsed with water and cleared in $10 \% \mathrm{KOH}$ for $45 \mathrm{~min}$ at $90^{\circ} \mathrm{C}$ and stained for 15 minutes in the ink solution.

After staining, 90 fragments of about $1 \mathrm{~cm}$ length were randomly selected and mounted between slide and cover, with 10 pieces per slide and examined under light microscopy. Mycorrhizal structures were observed (magnification 100) and for each root system showing at least one point of infection (penetration of hyphae in the root) is considered as mycorrhized. This technique calculates 5 parameters of infection by the method of (Giovannetti \& Mosse, 1980).

We also calculated the frequency of mycorrhization calculated by MYCOCALC software.

$>$ Frequency of mycorrhization in the root system:

$\mathrm{F} \%=(\mathrm{nb}$ of fragments myco/total $\mathrm{nb}) \times 100$

$>$ Intensity of the mycorrhizalcolonisation in the root system:

$\mathrm{M} \%=(95 \mathrm{n} 5+70 \mathrm{n} 4+30 \mathrm{n} 3+5 \mathrm{n} 2+\mathrm{n} 1) /(\mathrm{nb}$ total $)$

Where, $\mathrm{n} 5=$ number of fragments rated $5 ; \mathrm{n} 4=$ number of fragments 4 etc.

$>$ Intensity of the mycorrhizalcolonisation in the root fragments:

$\mathrm{m} \%=\mathrm{M} \times(\mathrm{nb}$ total $) /($ nbmyco $)$ 
$>$ Arbuscule abundance in mycorrhizal parts of root fragments:

$\mathrm{a} \%=(100 \mathrm{~mA} 3+50 \mathrm{~mA} 2+10 \mathrm{~mA} 1) / 100$

Where, $\mathrm{mA} 3, \mathrm{~mA} 2, \mathrm{~mA} 1$ are the $\%$ of $\mathrm{m}$, rated $\mathrm{A} 3, \mathrm{~A} 2, \mathrm{~A} 1$, respectively, with $\mathrm{mA} 3=(95 \mathrm{n} 5 \mathrm{~A} 3+70 \mathrm{n} 4 \mathrm{~A} 3+$ $30 \mathrm{n} 3 \mathrm{~A} 3+5 \mathrm{n} 2 \mathrm{~A} 3+\mathrm{n} 1 \mathrm{~A} 3) / \mathrm{nbmyco}) \times 100 / \mathrm{m}$ and the same for A2 and A 1 .

$>$ Arbuscule abundance in the root system:

$\mathrm{A} \%=\mathrm{a} \times(\mathrm{M} / 100)$

\subsection{Statistical Analysis}

The results obtained from the physico-chemical analysis of all soil samples were treated statistically by the one-factor analysis of variance (ANOVA) and the comparisons of the averages of the parameters measured were performed at the threshold of $5 \%$ by the test of Newman keuls with XLSTAT 2014 software.

\section{Results}

\subsection{Physico-Chemical Properties of the Soil}

From the values of particle size of clay, silt and sand, we reported the soil texture of cereal fields of the eastern parts of Algeria. The results show a clay loam soil in the regions of Sétif, Tébess, Jijel and Annaba, a loam clay soil in the regions of Constantine, Oum El Baouaghi, Batna and Biskra, and finally a loam sandy soil in Khenchela.

The results presented in Table 2 show a near to $8 \mathrm{pH}$ for all the soil samples, a $45 \%$ to $64 \%$ rate of saturation, an electrical conductivity between $\left(0.48\right.$ to $\left.2.59 \mathrm{mS} / \mathrm{cm}^{-1}\right)$ and total nitrogen content of 0.023 to $0.082 \%$. However, the phosphorus values are between $1.63 \%$ and $7.74 \%$. After variance analyzes, significant differences between the different sites $(\mathrm{P}<0.05)$ for all the parameters except the total nitrogen were revealed.

Table 2. Physico-chemical characteristics of the 10 soil samples

\begin{tabular}{|c|c|c|c|c|c|c|c|c|c|c|c|}
\hline \multirow[b]{2}{*}{ Wilaya } & \multicolumn{5}{|c|}{ Granulometry } & \multirow[b]{2}{*}{ Soil texture } & \multirow[b]{2}{*}{$\mathrm{pH}$} & \multirow{2}{*}{$\begin{array}{l}\text { Saturation } \\
(\%)\end{array}$} & \multirow[b]{2}{*}{$\begin{array}{l}\mathrm{CE} \\
\mathrm{mS} / \mathrm{cm}^{-1}\end{array}$} & \multirow{2}{*}{$\begin{array}{l}\text { Total } \\
\text { nitrogen } \\
(\%)\end{array}$} & \multirow{2}{*}{$\begin{array}{l}\text { Total } \\
\text { phosphorus } \\
(\%)\end{array}$} \\
\hline & $\begin{array}{l}\text { Gravel } \\
(\%)\end{array}$ & $\begin{array}{l}\text { Fine sand } \\
(\%)\end{array}$ & $\begin{array}{l}\text { Coarse sand } \\
(\%)\end{array}$ & $\begin{array}{l}\text { Loam } \\
(\%)\end{array}$ & $\begin{array}{l}\text { Clay } \\
(\%)\end{array}$ & & & & & & \\
\hline Setif & 0 & 4 & 3 & 30 & 38 & Clay loam & $7.90^{\mathrm{ab}}$ & $60^{\mathrm{abc}}$ & $1.04^{\mathrm{bc}}$ & $0.052^{\mathrm{a}}$ & $4.73^{c}$ \\
\hline Constantine & 2 & 4 & 4 & 21 & 35 & Loam clay & $7.94^{\mathrm{ab}}$ & $60^{\mathrm{abc}}$ & $0.48^{\mathrm{a}}$ & $0.023^{\mathrm{a}}$ & $3.98^{\mathrm{c}}$ \\
\hline Guelma & 7 & 10 & 13 & 24 & 32 & $\begin{array}{l}\text { Loam clay with a } \\
\text { gravel surface charge }\end{array}$ & $8.03^{\mathrm{ab}}$ & $64^{\mathrm{c}}$ & $2.25^{\mathrm{d}}$ & $0.027^{\mathrm{a}}$ & $2.03^{\mathrm{ab}}$ \\
\hline Oum El Bouaghi & 35 & 3 & 8 & 30 & 11 & $\begin{array}{l}\text { Loam clay with a } \\
\text { gravel surface charge }\end{array}$ & $7.87^{\mathrm{ab}}$ & $50^{\mathrm{a}}$ & $1.36^{\mathrm{c}}$ & $0.024^{\mathrm{a}}$ & $2.96^{\mathrm{b}}$ \\
\hline Batna & 4 & 3 & 3 & 32 & 23 & Loam clay & $8.27^{\mathrm{b}}$ & $60^{\mathrm{abc}}$ & $1.19^{\mathrm{bc}}$ & $0.076^{\mathrm{a}}$ & $1.63^{\mathrm{a}}$ \\
\hline Khenchela & 4 & 6 & 5 & 37 & 9 & Loam sandy & $7.94^{\mathrm{ab}}$ & $54^{\mathrm{ab}}$ & $0.90^{\mathrm{c}}$ & $0.055^{\mathrm{a}}$ & $1.92^{\mathrm{ab}}$ \\
\hline Tebessa & 2 & 5 & 4 & 22 & 45 & Clay loam & $7.92^{\mathrm{ab}}$ & $60^{\mathrm{abc}}$ & $2.40^{\mathrm{de}}$ & $0.080^{\mathrm{a}}$ & $2.86^{\mathrm{b}}$ \\
\hline Biskra & 4 & 4 & 4 & 32 & 11 & Loam clay & $7.95^{\mathrm{ab}}$ & $45^{\mathrm{a}}$ & $1.13^{\mathrm{bc}}$ & $0.028^{\mathrm{a}}$ & $2.46^{\mathrm{ab}}$ \\
\hline Jijel & 3 & 6 & 3 & 21 & 33 & Clay loam & $7.54^{\mathrm{a}}$ & $61^{\mathrm{abc}}$ & $2.56^{\mathrm{e}}$ & $0.082^{\mathrm{a}}$ & $7.06^{\mathrm{d}}$ \\
\hline Annaba & 2 & 3 & 2 & 21 & 30 & Clay loam & $7.66^{\mathrm{a}}$ & $61^{\mathrm{bc}}$ & $2.59^{\mathrm{e}}$ & $0.074^{\mathrm{a}}$ & $7.74^{\mathrm{d}}$ \\
\hline SEM & & & & & & & 0.27 & 5.50 & 0.76 & 0.14 & 2.12 \\
\hline Level of significance & & & & & & & $* * *$ & $* * *$ & $* * *$ & NS & $* * *$ \\
\hline
\end{tabular}

Note. Means with different letters within a variable indicate significant difference at $P=0.05$; NS (non significant).

Table 3 shows the number of extracted spores of $100 \mathrm{~g}$ of soil collected from the different sites surveyed in the eastern part of Algeria: 3-4 spores/100g of soil in the coastal zone, 5-12 spores/100g of soil in the semi arid zone and 6 spores $/ 100 \mathrm{~g}$ of soil in the arid zone. According to the analysis of variance of these results, no significant difference in the number of AMF spores were observed between arid, semi arid and coastal zones except for Khenchela (12 spores /100g of soil), Batna (11 spores/100g of soil) and Guelma (8 spores/100g of soil). 
Table 3. The number of spores present in a $100 \mathrm{~g}$ soil sample after extraction with the wet sieving method

\begin{tabular}{|c|c|c|c|c|c|c|c|c|c|c|}
\hline & \multicolumn{7}{|c|}{ Semi arid zone } & \multirow{2}{*}{$\begin{array}{l}\text { Arid zone } \\
\text { Biskra }\end{array}$} & \multicolumn{2}{|c|}{ Costal zone } \\
\hline & Sétif & Constantine & Guelma & Oum El Bouaghi & Batna & Khenchela & Tébessa & & Jijel & Annaba \\
\hline Spores number $/ 100 \mathrm{~g}$ of soil & $5^{\mathrm{c}}$ & $6^{\mathrm{c}}$ & $8^{\mathrm{b}}$ & $5^{\mathrm{c}}$ & $11^{\mathrm{a}}$ & $12^{\mathrm{b}}$ & $5^{\mathrm{c}}$ & $6^{\mathrm{c}}$ & $3^{\mathrm{c}}$ & $4^{c}$ \\
\hline
\end{tabular}

Note. * Each number of the same line followed by the same letter is not significantly different at the $5 \%$ threshold of Newman-Keuls test.

\subsection{Distribution and Diversity of Populations of Spores}

Our observations indicate the presence of 15 types of spores belonging to the genera Glomus, Acaulospora and Scutellospora (Figure 2). Glomus (type 1,2) is the most common genera that we found in all soil samples (Table 4), followed respectively by Acaulospora (type 5,6) and Scutellospora (type 3, 4).

Our characterization of spores based on morphological criteria (color, size and shape) show different colors (Black, dark brown, yellow, brown, orange, very pale yellow, orange and white). Also, different forms were noticed (spherical, ellipsoid and subglobose). The Biskra and Batna sites are characterized by a diversity of mycorrhizal spores. However at Jijel and Annaba sites we found only one kind of AMF spore.

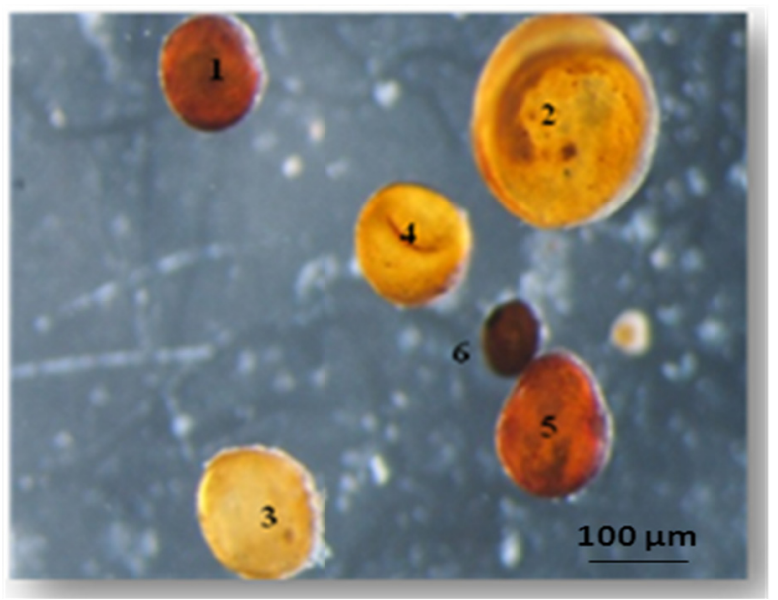

Figure 2. Overview of Glomus (1 and 2), Scutellospora (3 and 4) and Acaulospora (5 and 6) Spores under a binocular magnifier (X100)

Table 4. Characterization of spores on the basis of their principal characteristics (color, shape and size)

\begin{tabular}{|c|c|c|c|c|c|}
\hline Type & Colour & Shape & Diameter $(\mathrm{x}=\mu \mathrm{m})$ & Identification & Sites \\
\hline 1 & Dark brown & Globose & $64 X 66.5$ & Glomus & Batna and Khenchela \\
\hline 2 & Brown & Globose & $65 \times 70$ & Glomus & Annaba and Biskra \\
\hline 3 & Dark brown & Ellipsoide & $220 \times 150$ & Glomus & Khenchela and Guelma \\
\hline 4 & Yellow & Globose & $110 \times 115$ & Glomus & Batna, Sétif and Constantine \\
\hline 5 & Brown orange & Globose & 148.48 & Glomus & Jijel and Oum El Bouaghi \\
\hline 6 & Yellow & Globose & 117.76 & Glomus & Constantine, Sétif and Jijel \\
\hline 7 & Pale yellow & Subglobose & 95 & Acaulospora & Batna and Biskra \\
\hline 8 & Brown orange & Globose & 110 & Acaulospora & Khenchela \\
\hline 9 & Pale orange & Globose & 140 & Acaulospora & Biskra \\
\hline 10 & Pale yellow & Subglobose & 200 & Scutellospora & Batna \\
\hline 11 & Pale yellow & Subglobose & 190 & Scutellospora & Batna \\
\hline 12 & Orange & Globose & 125 & Unidentified & Tébessa \\
\hline 13 & White & Subglobose & 126.5 & Unidentified & Guelma and Biskra \\
\hline 14 & Pale brown & Subglobose & 120 & Unidentified & Batna \\
\hline 15 & Pale orange & Globose & 200 & Unidentified & Oum El Boughi \\
\hline
\end{tabular}




\subsection{Observation of Wheat Mycorrhized Roots}

The wheat roots inoculated with the isolated spores obtained from the sampled fields and grown in greenhouse pots show a typical colonization by AMF. The colonization is shown by the observation of typical AMF structures such as: arbuscules, vesicles, hyphae and spores.
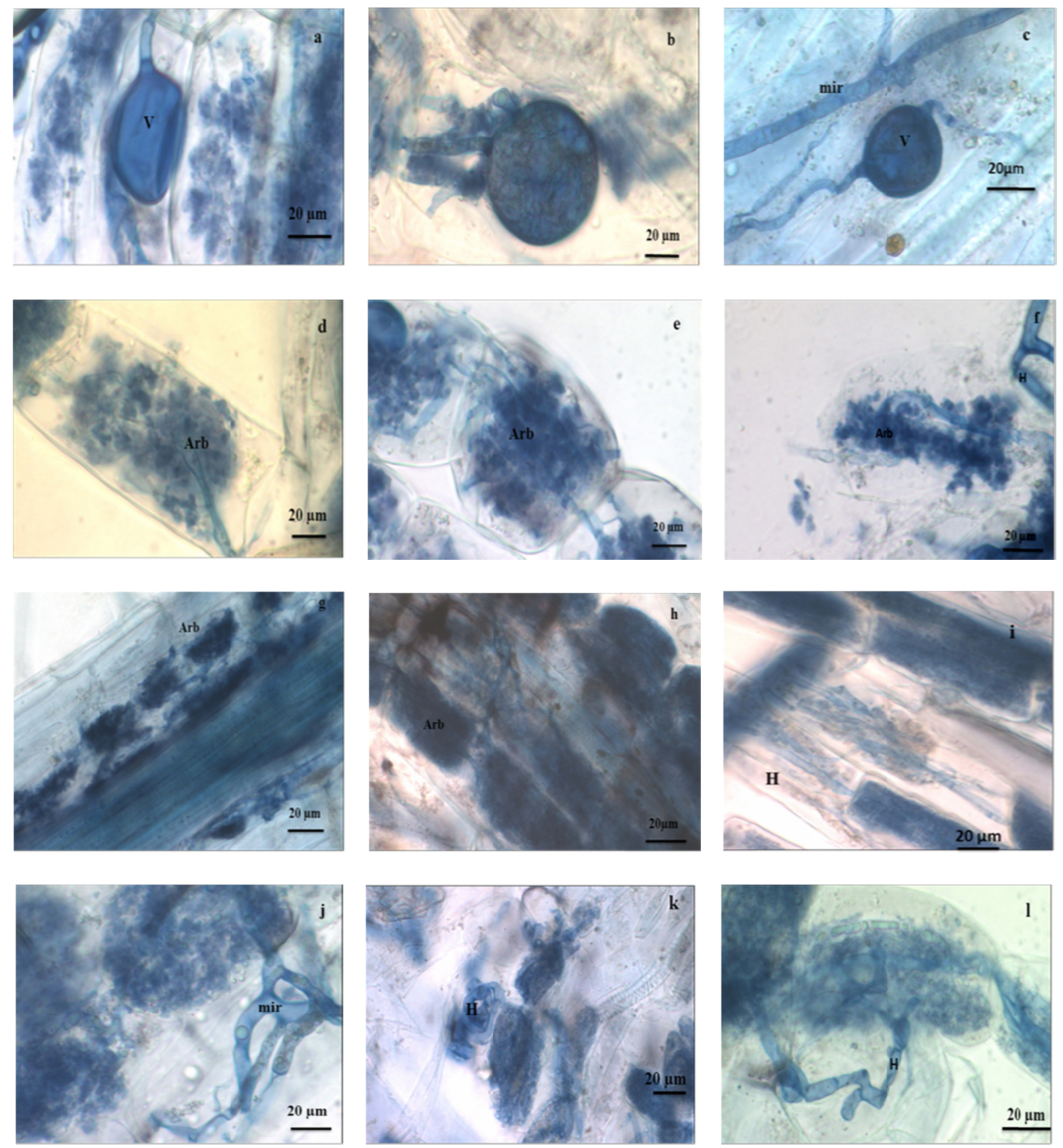

Figure 3. Morphology of mycorrhizal fungi in wheat inoculated roots. a, b and c) Oval vesicle between root cells inoculated with Glomus (X100), d) Arbuscules observed in the root of wheat inoculated with Glomus (X100), e)

Arbuscules and intra-radical hyphae observed in wheat roots inoculated with Scutellospora (X100), f) Hypha wheat root inoculated with Scutellospora (X100), g) Branched hyphae spiral in wheat roots inoculated with Acaulospora (X100), h) Straight hyphae in wheat roots inoculated with Glomus (X100), i) Branching arbuscules

along the inoculated roots by Glomus (X100), j) Branching arbuscules along the wheat roots inoculated Scutellospora (X100), k) Vaporous arbuscules in wheat roots inoculated with Scutellospora (X100), 1) Internal hyphae visible with lipid droplets in wheat roots inoculated with Acaulospora (X100)

Note. V: Vesicle, H: Hypha, Arb: arcuscule, mir: mycelium intra root. 


\subsection{Root Colonization Parameters in Durum Wheat Inoculated under Greenhouse Conditions}

We noticed after the root observation of three months durum wheat plants inoculation with 5 different morphotypes of AMF spores their mycotrophe character and its important frequency of mycorrhization (Figure 4).

Microscopic observations highlighted the presence of mycorrhizal fungi in the durum wheat roots and we estimated the extent of colonization, throughout 5 parameters. The frequency of mycorrhization reveals an average rate of $45 \%$ to $50 \%$ for plants inoculated with the morphotypes 1,3 and 4 . In the other hand, pots inoculated by the 2 and 5 morphotypes were less mycorrhized with a rate between $23 \%$ and $30 \%$.

The intensity of the mycorrhizal colonization of durum wheat inoculated with the 1,3 and 4 morphotypes were between 15 to $20 \%$ and between 5 to $7 \%$ for the morphotypes 2 and 5 .

The intensity of the mycorrhizal colonization of root fragments of durum wheat inoculated with the morphotypes $1,3,4$ and 5 were between 28 to $34 \%$, in contrast just $17 \%$ was noted with the 2 morphotype.

A $60 \%$ of arbuscule abundance was noticed with the morphotype 1, and 37 to $39 \%$ for the morphotypes 3,4 and 5 while $29 \%$ was noted with the 2 morphotype. Very low arbuscule abundance (from 2 to $13 \%$ ) in the roots systems was observed.
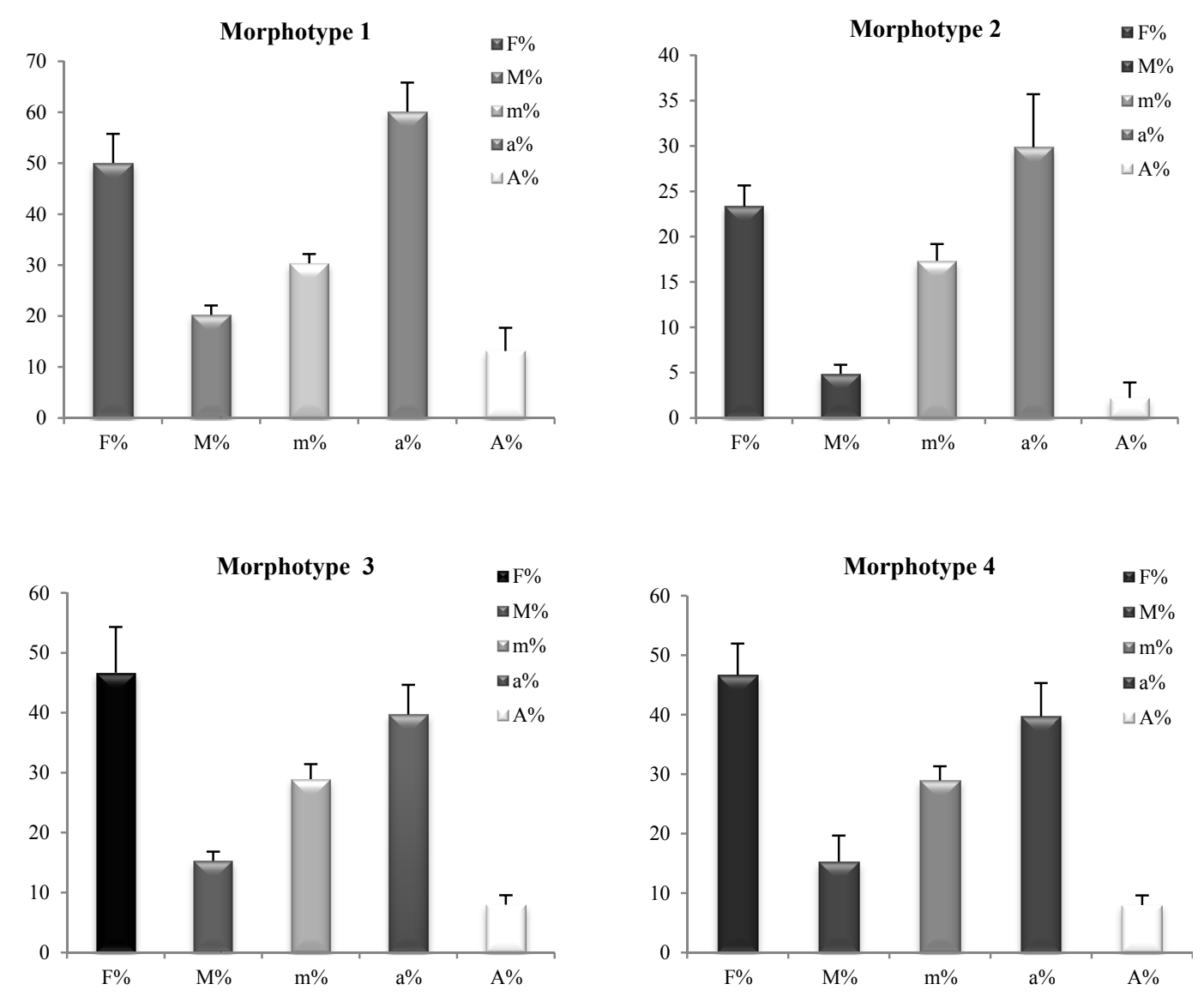


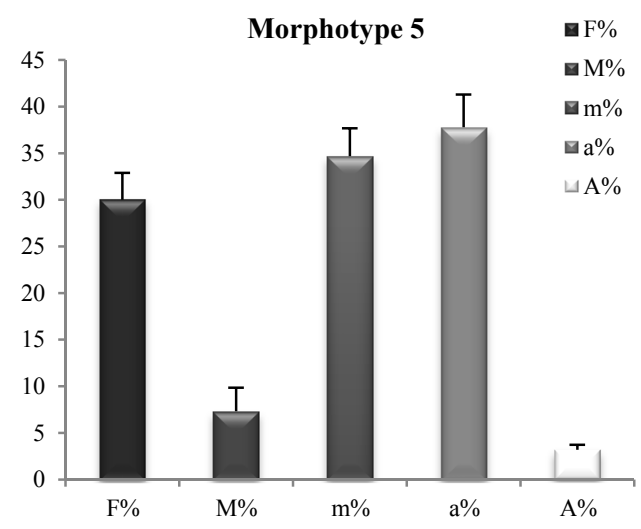

Figure 4. Estimation of the mycorrhizal infection of durum wheat Glomus spores morphotypes 1 and 3, Acaulospora spores morphotypes 2 and 4 and Scutellospora spores morphotype 5

Note. F: frequency of mycorrhization; $\mathrm{M}$ and m: relative and absolute intensity of mycorrhization respectively; A: arbuscules abundance in the root system and a: arbuscules abundance in the roots fragments.

\section{Discussion}

The results of the physico-chemical analysis of the soil presented in Table 2 show a clay loam, loam clay and loam sandy soil. Significant difference in all the parameters tested: $\mathrm{pH}, \mathrm{EC}$, saturation, phosphorus value except the nitrogen content was observed.

The $\mathrm{pH}$ recorded in different areas was alkaline which might be due to the mother rock of the study area (Djebaili et al., 1984; Halitime et al., 1988). We notice that the total phosphorus levels are low which may be due to drought, erosion or plant uptake (Li et al., 2004; Urosite et al., 2006).

To describe and identify the diversity of AMF spores associated with cereal fields of the east part of Algeria, we used the wet sieving method, microscopic observations and keys of determination based on the color, shape and size as well as the different structures; arbuscules, vesicles, intracellular and extracellular hypha to compared our results to INVAM and BEG sites.

Most of the explored sites which are characterized by the low rainfall show the presence of spores. Low mechanization practices that prevent the disruption of these cultivated areas are practiced which allow the development of AMF in the vicinity of the wheat fields.

A variety of spores are found in Batna (11 spore/100 g of soil) and Khenchela (12 spores/100 g of soil) (Table 4), these two regions are present in the arid zone where he analysis of soil type of revealed a clay loam soil that is reported to supports the installation of Glomales populations (Dalpé, 1989; Abe et al., 1994; Bâ et al., 1996).

The different mycorrhizal taxa identified on the basic of spores morphological and cellular characteristics belong to Glomus, Acaulospora and Scutellospora belonging to three families (Glomeraceae, Acaulosporaceae and Gigasporaceae) respectively.

In the coastal zone, only Glomus was observe, Glomus and Scutellospora were found in the arid zone and the three genera were observed in the semi-arid zone.

In addition, AMF spores were found to be rare in the littoral zone (Annaba and Jijel). This could be explained by the high content of soil salts $\left(\mathrm{EC} 2 \mathrm{mS} / \mathrm{cm}^{-1}\right)$. Thoen, 1987 have shown that salty soils are not favorable for the installation of endomycorrhizal symbioses.

The predominance of Glomus and Acaulospora in semi arid and arid soils is consistent with previous results obtained in Algeria by Fraga-Beddiar and Le Tacon (1990) on alder, Chafi and Fortas (1999) on truffles, Adjoud-Sadadou and Halli-Harrga (2000) on eucalyptus, Hamza (2010) on watermelon and Neffar (2012) on figs. Both Acaulospora and Scutellospora are less abundant and poorly represented compared to Glomus which might be due to the difficulty encountered in their observation and identification as they become sessile because of the fragility of their related structures (spore sacs and connecting hyphae).

Overall, we found in the 10 prospected regions, six species of yellow, brown, dark brown and orange brown color Glomus. These isolated spores are of globose, subglobose and ellipsoid shape, collected in the 100 and 250 $\mu \mathrm{m}$ fractions with a size ranging from (64 to $220 \times 66.5$ to $150 \mu \mathrm{m})$. 
In all the studied regions, the diversity of AMF was of a maximum 5 species found in the Batna region, which is characterized by a clay loam soil, 4 species of AMF were recorded in the region of Biskra characterized by a dry land. Glomus spores are among the most frequently found species. According to several authors, species of Glomus are distributed in different parts of the world and dominate the communities in arid, semi-arid and temperate zones (Li \& Zhao, 2005; Gay et al., 2006; Uhlmann et al., 2006). And according to Pande and Trafdar (2004), the AMF dominate the alkaline and neutral soils under various edaphic conditions.

The observation of inoculated wheat roots by the isolated spores in pots and under greenhouse conditionsshow colonization by AMF. These fungi form characteristic structures such as arbuscules, different shapes of vesicles, intra and intercellular hyphae and spores. Furthermore, the vesicles presence inside cortical tissues (Figure 3) partly confirms the predominance of Glomus as they are the only kind that producesvesicles inside the host tissue (Smith \& Read, 2008).

A high intensity of the mycorrhizal colonization of the roots of durum wheat inoculated by the 1,3 and 4 (Glomus, Acaulospora) morphotypes was observed. In addition, the arbuscule abundance (a) was higher in roots inoculated with the morphotype 1 (Glomus) with a $60 \%$ rate but a very low arbuscule abundance of the mycorrized fragments was noticed (13\%). This might be due to the short life of arbuscules (1 to 3 weeks) which degenerate and will be replaced by hyphas and vesicles that persist until the death of the cell.Our results are similar to those of Saad (2009). Thus the level of colonization of the roots by the 1 and 3 (Glomus) morphotypes are most significant and would be interesting for the production of inoculums.

\section{Conclusion}

Mycorrhizal associations play important roles in the functioning and the stability of different ecosystems. Many researchers have been studying the role of AMF in productivity. These studies have shown the importance, the diversity and abundance of mycorrhizal propagules.

This study focused on the diversity of AMF and characterization of the isolated spores from the surveyed areas. The characterization of the spores revealed the predominance of Glomus (Glomeraceae) and the presence of the two genera Acaulospora and Scutellospora. Thus our work revealed the phenotypic description of the main spores found in the soil.

It would be interesting to continue this research highlighting the diversity of Glomales in the east of Algeria extracting significant numbers of spores for systematic studies in order to reinforce the role of mycorrhizal symbiosis as a biological agent improving the growth of cereals in the arid and semi arid areas, to produce adequate inoculums and to produce a bank of AMF.

\section{Acknowledgements}

We thank the ITGC (Institue Thechnique des Grandes Culture) for providing seeds. We also thank Mrs Ryma Bouldjej and Radia Jeghal for their help. We would particularly like to thank Mrs Nadjet Djemouai for her help and translalation.

\section{References}

Abe, J. I. P., Masuhara, G., \& Katsuya, K. (1994). Vesicular-arbuscular mycorrhizal fungi in coastal plant communities. Spore formation of Glomus sp. predominantes under a patch of Elymus mollis. Mycoscience, 35, 233-238. https://doi.org/10.1007/BF02268443

Adjoud-Sadadou, D., \& Halli-Harrga, R. (2000). Occurrence of arbuscularmycorrhiza on aged Eucalyptus. Mycorrhiza, 9, 287-290. https://doi.org/10.1007/PL00009993

AFNOR. (1990). Granulats, analyse granulométrique par tamisage (pp. 18-560). Norme.

Allen, M. F., \& Boosalis, M. (1983). Effects of two species of VA mycorrhizal fungi on drought tolerance of winter wheat. New Phyto., 93, 67-76. https://doi.org/10.1111/j.1469-8137.1983.tb02693.x

Bâ, A. M., Dalpi, Y., \& Guissou, T. (1996). Les Glomales d'Acacia holosericea et d'Acacia mangium. Bois et forets des tropiques (p. 250).

Bever, J. D., Schultz, P. A., Pringle, A., \& Morton, J. B. (2001). Arbuscular mycorrhizal fungi: More diverse than meets the eye, and the ecological tale of why. Bioscience, 51, 923-931. http://dx.doi.org/10.1641/ 0006-3568(2001)051[0923:AMFMDT]2.0.CO;2

Cade-Menun, B. J., Berch, S. M., \& Bomke, A. A. (1991). Seasonal colonization of winter wheat in South Coastal British Columbia by vesicular arbuscular mycorrhizal fungi. Can. J. Bot., 69, 78-86. https://doi.org/10.1139/b91-011 
Chafi, M. E., \& Fortas, Z. (1999). Les mycorhizes des plantes des zones arides algériennes. Bois et Forêts des Tropiques, 262(4), 77-79.

Dai, M., Hamel, C., Bainard, L. D., Araud, M. St., Grant, C. A., Lupwayi, N. Z., Malhi, S. S., \& Lemke, R. (2014). Negative and positive contributions of arbuscular mycorrhizal fungal taxa to wheat production and nutrient uptake efficiency in organic and conventional systems in the canadian prairie. Soil Biology \& Biochemistry, 74, 156-166. http://dx.doi.org/10.1016/j.soilbio.2014.03.016

Dalpé, Y. (1989). Inventaire et répartition de la flore endomycorhizienne de dunes et de rivages maritimes du Québec du Nouveau-Brunswick et de la nouvelle Ecosse. Rev. Ecol. Syst., 116, 219-236.

Djebaili, S. (1984). Steppes algériennes: Phytosociologie et écologie (p. 177). Office des Publications Universitaires, Alger.

Djermoun, A. (2009). La production céréalière en Algérie: Les principales caractéristiques. Revue Nature et Technologie, 1, 45-53.

Fraga-Beddiar, A., \& Le Tacon, F. (1990). Interactions between a V.A. mycorrhizal fungus and Frankia associated with alder (Alnus glutinosa L. Gaertn.). Symbiosis, 9, 247-258.

Gai, J. P., Christie, P., Feng, G., \& Li, X. L. (2006). Twenty years of research on community composition and species distribution of arbuscularmycorrhizal fungi in China: A review. Mycorrhiza, 16, 229-239. https://doi.org/10.1007/s00572-005-0023-8

Gerdemann, J., \& Nicolson, T. (1963). Spores of mycorrhizal Endogone species extracted from soil by wet sieving and decanting. Transactions of British Mycological Society, 46, $235-244$. http://dx.doi.org/10.1016/S0007-1536(63)80079-0

Giovannetti, M., \& Mosse, B. (1980). An evaluation of techniques for measuring vesicular arbuscular mycorrhizal infection in roots. New Phytol., 84, 489-500. http://dx.doi.org/10.1111/j.1469-8137.1980. tb04556.x

Halitim, A. (1988). Sols des régions arides (p. 384). Office des Publications Universitaires, Alger.

Hamel, C. (1996). Prospects and problems pertaining to the management of arbuscular mycorrhizae in agriculture. Agriculture Ecosystems and Environment, 60, 197-210. Retrieved from http://www.sciencedirect.com/science/article/pii/S0167880996010717

Hamza, N. (2014). Application des mycorhizes arbusculaires en culture maraîchère cas de la pastèque (Citrullus lanatus) (Thèse de Magister). Université Ferhat Abbas, Sétif, Algérie. Retrieved from http:/www.univ-setif.dz/MMAGISTER/images/facultes/SNV/2014/HAMZA\%20Nabila.pdf

Hu, J., Lin, X., Wang, J., Cui, X., Dai, J., Chu, H., \& Zhang, J. (2010). Arbuscular mycorrhizal fungus enhances P acquisition of wheat (Triticum aestivum L.) in a sandy loam soil with long-term inorganic fertilization regime. Appl. Microbiol. Biotechnol, 88, 781-787. http://dx.doi.org/10.1007/s00253-010-2791-0

Jansa, J., Mozafar, A., \& Frossard, E. (2005). Phosphorus acquisition strategies within arbuscular mycorrhizal fungal community of a single field site. Plant and Soil, 276, 163-176. http://dx.doi.org/10.1007/ s11104-005-4274-0

Li, F. M., Song, Q. H., Jjemba, P. K., \& Shi, Y. C. (2004). Dynamic of soil biomass microbial C and soil fertility in Cropland mulched with plastic film in a semi arid agro-ecosystem. Soil Biology and Biochemistry, 36, 1893-1902. http://dx.doi.org/10.1016/j.soilbio.2004.04.040

Li, T., \& Zhao, Z. (2005). Arbuscula rmycorrhizas in a hot and arid ecosystem in South-West China. Applied Soil Ecology, 29, 135-141. http://dx.doi.org/10.1016/j.apsoil.2004.11.005

Neffar, S. (2012). Etude de l'effet de l'âge de plantation de figuier de Barbarie (Optuntia ficus indica L.Miller) sur la variation des resources naturelles (sol et végétation) des steppes algériennes de l'Est. Cas de Souk ahras et Tébessa (Thèse de doctorat). Université BADJI Mokhtar, Annaba, Algérie. Retrieved from http://biblio.univ-annaba.dz/wp-content/uploads/2014/06/These-Doc-Neffar.pdf

Neveen, B. T., \& Bahaa, T. S. (2011). Influence of arbuscular mycorrhizae on yield, nutrients, organic solutes, and antioxidant enzymes of two wheat cultivars under salt stress. Journal of Plant Nutrition and Soil Science, 174(2), 283-291. http://dx.doi.org/10.1002/jpln.201000051

Pande, M., \& Tarafdar, J. C. (2004). Arbuscular mycorrhizal fungal diversity in neem based agroforestry systems in Rajasthan. Applied Soil Ecology, 26, 233-241. http://dx.doi.org/10.1016/j.apsoil.2003.12.009 
Rinaudo, G. (1970). Fixation biologique d'azote dans trois types de sols de rizière de Côte d'Ivoire. Thèse d'Ingénieur Docteur Université de Montpellier, France.

Smith, S. E., \& Read, D. J. (2008). Mycorrhizal symbiosis (3rd ed., p. 815). Clarendon Press, Oxford.

Strullu, D. G., Perrin, R., Plenchette, C., \& Garbaye, J. (1991). In Tech et Doc. Lavosier (Ed.), Les mycorrhizes des arbres et plantes cultivées.

Uhlmann, E., Gorke, C., Petersen, A., \& Oberwinkler, F. (2006). Arbuscular mycorrhizae from arid parts of Namibia. Journal of Arid Environments, 6, 221-237. http://dx.doi.org/10.1016/j.jaridenv.2005.05.002

Urioste, A. M., Hevia, G. G., Hepper, E. N., Anton, L. E., Bono, A. A., \& Buschiazzo, D. E. (2006). Cultivation effects of the distribution of organic carbon, total nitrogen and phosphorus in soils of the semiarid region of Argentinian Pampas. Geoderma, 136, 621-630. http://dx.doi.org/10.1016/j.geoderma.2006.02.004

Vierheilig, H., Coughlan, A. P., Wyss, U., \& Piche, Y. (1998). Ink and Vinegar, a Simple Staining Technique for Arbuscular-Mycorrhizal Fungi. Applied and Environmental Microbiology, 64(12), 5004-5007. Retrieved from https://www.ncbi.nlm.nih.gov/pmc/articles/PMC90956/pdf/am005004.pdf

\section{Copyrights}

Copyright for this article is retained by the author(s), with first publication rights granted to the journal.

This is an open-access article distributed under the terms and conditions of the Creative Commons Attribution license (http://creativecommons.org/licenses/by/4.0/). 